COBISS: 1.01

\title{
DATING ANCIENT CAVES AND RELATED PALAEOKARSTS
}

\section{DATIRANJE STARIH JAM IN Z NJIMI POVEZANEGA PALEOKRASA}

\author{
R. ARMSTRONG L. OSBORNE ${ }^{1}$
}

${ }^{1}$ R. Armstrong L. Osborne, School of Development \& Learning, A35, University of Sydney, NSW, 2006., Australia 


\begin{abstract}
UDC $902.035: 551.44$

R. Armstrong L. Osborne: Dating ancient caves and related palaeokarsts

There are few cases of open caves that have been reliably dated to ages greater than $65 \mathrm{Ma}$. This does not mean that such caves are extremely rare, rather it is difficult to reliably establish that a cave, or palaeokarst related to a cave, is this old. Relative dating methods such as: - regional stratigraphic, lithostratigraphic, biostratigraphic, relative climatic, relative isotopic, morphostratigraphic, and regional geomorphic are very useful. They suffer however from significant difficulties, and their results lack the impact of a crisp numerical date. While many of the methods used to date younger caves will not work over the required age range, some isotopic methods and palaeomagnetic methods have been applied with varying degrees of success. While finding something to date and having it dated is difficult enough, producing the date is rarely the end of the story. The difficult issue is not the date or relative correlation itself, but what the date or correlation means. Demonstrating that caves are ancient seems to rapidly become beset with the old adage that "extraordinary claims require extraordinary proof". The presence of a well-dated or correlated sediment in a cave does not necessarily mean that the cave is that old or older. Perhaps the dated material was stored somewhere in the surrounding environment and deposited much more recently in the cave. A lava flow in a cave must be demonstrated conclusively to be a flow, not a dyke or a pile of weathered boulders washed into the cave. It must be conclusively shown that dated minerals were precipitated in the cave and not transported from elsewhere. There seems little doubt that in the future more ancient caves, or ancient sections of caves, will be identified and that as a result our perception of the age of caves in general will change.
\end{abstract}

Key words: speleology, age of cave, ancient cave, dating methods.

Izvleček

UDK $902.035: 551.44$

\title{
R.A.L. Osborne: Datiranje starih jam in z njimi povezanega paleokrasa
}

Je le nekaj primerov odprtih jam, ki bi imele zanesljivo določeno starost nad 65 milijonov let. To ne pomeni, da so take jame izredno redke, ampak da je težko zanesljivo ugotoviti, da so oziroma paleokras, povezan z njimi, res tako stare. Relativne metode datiranja, kot so regionalno stratigrafsaka, litostratigrafska, biostratigrafska, relativno klimatološka, relativno izotopska, morfostratigrafska in regionalno geomorfološka, so zelo uporabne. Imajo pa pomembne pomanjkljivosti, saj njihovi izsledki ne temelje na jasnih številčnih podatkih. Medtem ko marsikatera od metod, ki so uporabne za datiranje mlajših jam, ni uporabna za omenjeno starost, pa je bilo uporabljenih več izotopskih in paleomagnetnih metod z različnim uspehom. Težko je najti snov za datiranje in jo datirati, a sama starost še ni konec zgodbe. Težava ni z datiranjem ali s korelacijo, ampak v tem, kaj starost oziroma korelacija pomenita. Dokazovanje, da so jame stare, je hitro odpravljeno s pregovorom »Izredni izsledki zahtevajo izredne dokaze«. Dobro datirani ali korelirani sedimenti v jami še ne pomenijo, da je jama toliko stara ali starejša. Morda je bilo datirano gradivo odloženo nekje v okolici in šele mnogo kasneje preneseno v jamo. Lavin tok v jami mora biti neizpodbitno določen kot lavin tok, ne pa da je dyke ali balvani, prenešeni $\mathrm{v}$ jamo. Neizpodbitno mora biti dokazano, da so bili datirani minerali izločeni v jami in ne preneseni od nekod drugod. Nedvomno bo v bodoče spoznanih več starih jam ali njihovih delov in zaradi tega se bo tudi naše pojmovanje o starosti jam v celoti spremenilo.

Ključne besede: speleologija, starost jam, stara jama, metode datiranja. 


\section{INTRODUCTION}

For much of the Twentieth Century it was generally thought that landscapes in general were young, mostly Pleistocene or younger and so were caves. Not only were caves and the karsts in which they developed thought to be young, they were mostly thought to have been produced by a single process acting over a single short time span. From the late 1970s onwards ideas about both karsts and landscapes began to change. Karstification became recognised as a multiphase or polyphase process from the work of many authors such as Avais (1972), Belloni et al. (1972), Daranyi (1972) and Herak (1972). This lead Komatina (1975) to note that: -

"karst must be considered in most cases as a complex phenomena grossly dependent on the stratigraphic and tectonic evolution of the region, i.e. as a complex formation of stratigraphically different palaeokarsts and recent karsts."

At the same time as karsts were being recognised as complex and multiphase, landscapes particularly in Australia, were being seen to be much older than had been previously thought. By the early 1990s it was quite uncontroversial for Gale (1992) to state that: -

" a significant component of the landscape of the continent [i.e. Australia] has its origin beyond the start of the Quaternary and, often beyond the start of the Cenozoic." [Gale, 1992, p 323]

It was in this intellectual environment that I began in the early 1980s to recognise palaeokarst deposits exposed in eastern Australian caves and realise that these caves were multiphase (Osborne, 1984a). Recognition that the landscapes were old meant that not only were there ancient phases of cave development in these karsts, but also that the most recent phase (or phases) of development forming the presently open caves could also be very old, perhaps early Tertiary or Late Cretaceous.

This paper explores a problem that I have attempted to solve on numerous occasions and in various settings, How to date ancient caves? A number of possible methods are described and evaluated here. Frequently it has been necessary to use examples from young caves when illustrating these approaches. Finally the general problems that arise when attempting to date ancient caves are discussed, particularly the problem of getting colleagues and the audience to accept the results.

\section{ANCIENT CAVES}

If by cave we mean an open cavity accessible to humans, then very few have been reported that are undoubtedly older than the Cainozoic. Palaeokarst deposits however date back to the Proterozoic (Martini, 1981). The idea of accessible caves having geologically significant ages is relatively recent and there are significant problems in defining what is meant by the age of a cave (see Bosak, 2002 and Osborne, 2000, 2002). I include among ancient, open caves those that formed in the distant past, were filled and were then later wholly, or partly, re-excavated. In the case of these caves, it is the date of initial excavation that is critical. The very few open karst caves large enough for human access older than the Cenozoic for which there are well-justified ages are listed in Table 1.

The Middle Carboniferous caves in the Black Hills of South Dakota were described by Palmer and Palmer (2000, p 279) as: - “... mainly isolated domed chambers, rather than continuous systems. They are rarely more than $10 \mathrm{~m}$ in height or more than $100 \mathrm{~m}$ in lateral extent..."

The Silurian caves described by Kahle (1988) are small features 1.5-50 m across exposed in quarry faces. Many are filled with sediment and some are open. It is not completely clear, however, 
if the open caves are truly ancient in origin or are more recent features intersecting older palaeokarst deposits.

The caves at Jenolan containing the Carboniferous clay remnants described by Osborne et al. (in prep) are larger and more complex than other accessible Palaeozoic caves yet described, and may be the oldest complex cave system accessible to humans yet recognised.

Recent work (e.g. Adura et al., 2002; Jeannin et al., 2000) is showing that "young" caves are much older than had been previously thought. Thus, "young" caves are getting older. The challenge now is to expand the list above by finding reliable ways to date potentially old caves.

\section{The paradox of survival}

It has become very clear in Australia at least, that many landsurfaces have survived since the Mesozoic or earlier, not as exhumed features but exposed at the surface (Gale, 1992). As Gale pointed out, low denudation rates cannot on their own account for the survival of ancient landforms, denudation must also be localised and remain localised over long periods of time.

The situation for karst, however, is more difficult. While workers with an interest in polycyclic karst or multiple karstification find more and more caves with long, complex and varied histories of development, process geomorphologists continue to find evidence of quite rapid denudation. This is a paradox: how can old caves and karst landforms survive if the surface is being denuded, even at relatively slow rates?

This conundrum was first described in the context of Australian caves by Bud Frank, who on observing a palaeokarst sediment with a ferruginous cement, exposed in the wall of a more modern cave at Borenore in central New South Wales, Australia, commented: -

“... these processes take a considerable length of time and probably longer,

in fact, than the normal life-span of a cave system." [Frank, 1973, p 36]

It seems likely that factors other than low denudation rates and localised denudation, such as "karst resistance", shallow burial, changes in water level due to blockage of caves by sediment and block faulting may also be involved.

\section{Where might old Caves be found?}

I found old caves by chance, I just happen to work in a region where they occur. Perhaps a more systematic approach to finding old caves is possible. One would anticipate that locations where old caves occur and survive would need at least some: -

- old bedrock

- old landsurfaces

and, if old caves are exhumed: -

- proximity to unconformities

- a history of vertical movement

Some of the oldest carbonate rocks and old landscapes coincide in parts of Australia (e.g. Proterozoic dolostones in South Australia), Brazil (in Proterozoic dolostones of the San Francisco Craton) and in the Transvaal of South Africa. A quick look at Table 1 will show that the old open caves have not, at least yet, been found in these localities or in other really ancient landscapes. The ancient caves occur in Palaeozoic rocks in areas of old landscapes (perhaps Mesozoic) or exhumed at unconformities. This may also tell us that the age of the rock and landscape cannot by themselves 
R. Armstrong L. Osborne: Dating ancient caves and related palaeokarsts

\begin{tabular}{|c|c|c|c|c|}
\hline \multicolumn{5}{|c|}{ Excavation Age } \\
\hline Ma/Period & Dating & Host Rock Age & Location & Reference \\
\hline $67-70 \mathrm{Ma}$ & $\mathrm{C}(\mathrm{T})$ & Devonian & Bohemian Karst, Czech Republic & Bosak (1998) \\
\hline $92 \mathrm{Ma}$ & $* \mathrm{U}-\mathrm{Pb}$ & Permian & Guadalupe Mts., New Mexico USA & Lundberg et al. (2001) \\
\hline $320-310 \mathrm{Ma}$ & $\mathrm{C}(\mathrm{S})$ & Early Carboniferous & Black Hills, South Dakota USA & Palmer \& Palmer (2000) \\
\hline $345-339 \mathrm{Ma}$ & $* \mathrm{~K}-\mathrm{Ar}$ & Late Silurian & Jenolan Caves, NSW, Australia & Osborne et al. in prep \\
\hline ? Silurian & $\mathrm{C}(\mathrm{S})$ & Silurian & West Ohio, USA & Kahle (1988) \\
\hline
\end{tabular}

Table 1: Open karst caves older than 65 Ma large enough for human access

account for caves surviving. A systematic search of some likely localities is probably a good idea for future work.

\section{But is there anything that can be dated?}

Workers on young caves are familiar with applying techniques such as U-Th that work over a relatively short time range. An excellent review of various cave dating methods is given by Bosak (2002). With ancient caves a range of different approaches need to be considered which can cope with geologically significant periods of time. In fact, as the time length increases, the approaches to dating necessarily become more geological and less geomorphological in character.

\section{RELATIVE APPROACHES}

\section{REGIONAL GEOLOGICAL/STRATIGRAPHIC}

The most frequently used approach to dating ancient caves and related palaeokarsts is to try to fit them into the established geological history for the area. Regional geological/stratigraphic correlation raises different questions for different types of caves and deposits: -

- Meteoric caves: -

- Thermal/hydrothermal caves: -

- Artesian caves: -

- Clastic sediments: -

- Marine sediment: -

- Volcaniclastics: -

- Fills unconformable with bedrock: -
When was the limestone exposed at the surface?

When was an appropriate heat source available? When was there an active source aquifer and the correct type of cover in place?

When could material with a particular provenance have entered the cave?

When was there a marine transgression?

When was there an eruption with the right chemistry?

When was there an orogeny? 
A sound and detailed knowledge of the local and regional geological history, palaeogeography and palaeoclimate is a prerequisite for correlating cave and karst history with geology. For instance, the likely sources of clastic sediments may be located a great distance from the karst under investigation and their transport to and deposition in the caves will only be possible under specific palaeogeographic or climatic conditions.

The following examples, based on experiences of attempting these correlations in eastern Australia, illustrate some of the issues that may arise.

\section{Relationship to Unconformities and Disconformities}

It is essential to understand the history of burial and surface exposure of a karst if one is to understand the timing of meteoric speleogenesis and clastic sedimentation. That being said, one must not conclude that the lack of sediments of a particular age necessarily indicates remoteness from the surface, as cave entrances can easily become blocked.

While exposure at the surface, as indicated by a regional unconformity between the karst rock and overlying beds, may indicate that meteoric karstification was possible at that time, it does not of necessity mean that any of the karst features have survived. Extensive glaciation, for instance, could have removed all or much of the karstified zone prior to deposition of the covering strata. Thus, in one location, a fluvioglacial unit may directly overlie a limestone block that contains no related fills, while a few kilometres away fills related to the unconformity may be located with ease.

Given the increasing evidence for deep speleogenesis we must also be careful not to assume that all ancient cave development is indicative of surface exposure in the past.

Four of the five ancient caves in Table 1 are located close to major unconformities, as are most of the complex multiphase caves I have investigated in eastern Australia.

\section{The problem of rare relicts}

It is not unusual for caves and palaeokarst deposits to contain the only remaining evidence of significant geological events. These may be:

1. relicts of sediments or lava flows whose surface outcrops have been totally (or mostly) eroded away or

2. deposits that are the only evidence there ever was for a particular event, or its timing.

Easily eroded materials such as loess or fine volcaniclastics are the most common examples of the first category. Vast quantities of Pleistocene red earth (loess) have been known in eastern Australian caves for many years, but only recently have traces of these sediments been recognised on the landsurface. Similarly, recent work at Jenolan Caves (Osborne et al. in prep) has identified relict volcaniclastic deposits that are probably the only physical evidence for a long theorised period of Palaeozoic vulcanism. Recent work has also revealed the presence of volcaniclastic palaeokarst exposed in Cathedral Cave at Wellington Caves, however there is no evidence yet of its age.

It may be difficult to convince mainstream geologists that a small relict deposit in a cave is sufficiently good evidence to challenge well-established ideas about regional geological history.

\section{Relationship to Tectonism}

While caves may survive through epirogneic uplift, block faulting and some types of thrusting, they are not likely to survive through periods of intense folding. Open caves and undisrupted filled 
caves are therefore younger than the last period of intense tectonism affecting the host rock. Where the host rock is of considerable age, this is an important way of setting a maximum age for a cave or palaeokarst. Dated undisturbed palaeokarsts can conversely set a minimum age for tectonism.

A good example of palaeokarst being used to date tectonism comes from Tasmania. The presence of Late Devonian spores in the Eugenana Beds, a sequence of palaeokarst sediments that are exposed in a limestone quarry, was used by Banks and Burns (1962) to set a minimum age for the Tabberabberan Orogeny, a major Early Palaeozoic folding event.

\section{Relationship to volcanism/plutonism}

Volcanism can be a source of volcaniclastics and lavas entering caves, while plutonism can result in dyke emplacement and contact metamorphism. Both can produce thermal waters and hydrothermal fluids and result in thermal/hydrothermal speleogenesis. An understanding of the volcanic, plutonic and thermal history of karst areas is essential when attempting to understand their history.

For example, Bosak (1998) correlated thermal cave development with an established thermal and volcanic chronology in the Koneprusy region of the Bohemian Karst (Czech Republic). Another example is the lack of metamorphorphism of crystal linings and crackle breccias at Wombeyan Caves (N.S.W., Australia), which allowed me to determine that they were younger than the thermal event responsible for metamorphism of the marble bedrock (Osborne, 1993b).

\section{Changes in geological interpretation}

While geological interpretations seem less likely to change than geomorphic ones, changes in geological interpretation can be significant where dating of karst and palaeokarst is concerned (see below). One eastern Australian example illustrates some of the consequences.

Wombeyan Caves in New South Wales are developed in a body of marble, surrounded on all sides by porphyry and intruded by granite. In the 1950s, it was thought that both the porphyry and the granite were intrusive. Thus, the marble was interpreted as being a roof pendant. Interpretations of the karst geomorphology up until the early 1980s (e.g. Jennings et al., 1982) were based on this assumption. The surface of the karst, which forms a low basin, surrounded by hills of porphyry, was seen to result from differential erosion of the marble. Small inliers of porphyry within the marble were interpreted as stocks. The lack of deep caves and the failure of a major stream to be captured underground was seen to be a consequence of the presence of an igneous barrier at a shallow depth below the present ground surface.

In the early 1980s, a more modern interpretation of the porphyry as an effusive volcaniclastic produced by large exploding volcanoes emerged (Powell \& Fergusson, 1979; Fergusson, 1980; Cas et. al., 1981). This allowed me to recognise that much of the present karst surface was an exhumed palaeokarst unconformity and led me to search for paleokarst features. I found a range of features including filled grikes, filled dolines and filled caves both in surface exposure and underground (Osborne, 1993b). The volcaniclastic inliers were re-interpreted as filled karst depressions in the Devonian surface.

\section{Insufficiently Robust Bedrock Geology}

The underlying assumption informing this paper is that caves and karst are long-surviving, complex multiphase and multiprocess entities. Consequently, attempting to relate them to the geological 
history of their surroundings may illuminate inadequacies in the local and regional geology, or fail due to the inadequate knowledge of the local and regional geology.

Just as we in the karst arena have been recognising the complexity of karst, there as been a general trend to recognize that many geological boundaries are diachronous. Volcanism, plutonism, tectonism and epeirogenesis are increasingly seen not as instantaneous, but as multiphase events that occur over periods of time and move laterally through space. For example, lithostratigraphy across a basin will not equate to chronostratigraphy everywhere. Similarly, a regional tectonic or epeirogenic event will not occur at the same time hundreds of kilometres from where it has been dated.

These problems continue to arise in my work in eastern Australia where many of the plutonic and volcanic rocks that are significant to karst history have not been radiometrically dated and where the dating of regional tectonic events often relies on work undertaken hundreds of kilometres away.

It is very important to check on the reliability of accepted stratigraphic dating when making correlations between karst chronologies and bedrock geology. The problem may be not in the karst, but in the bedrock. Time-consuming and expensive work may be required to resolve the bedrock geological problems before the karst history can be completed.

\section{LITHOSTRATIGRAPHIC}

The internal stratigraphy of palaeokarst deposits and cave fills can be established by careful lithostratigraphic work. Cave sediment and palaeokarst stratigraphy is notoriously difficult (Osborne, 1984b), but careful stratigraphic work is an essential precursor to other types of relative dating and to all types of absolute dating. One very important feature of cave sediment and palaeokarst stratigraphy is that superposition, the founding idea of stratigraphy recognised by Neils Stensen in 1699 , is not generally applicable, except within discrete sequences. Crosscutting relationships in three dimensions are typically more important than vertical relationships.

Not only must relationships within sedimentary sequences be reliably established, but also attempts need to be made to correlate between different sequences within the caves and to recognise the relationships between the strata and cave morphology. Stratigraphy depends on the observation of critical boundaries and relationships. The lack of continuity and dramatic lateral facies changes over small distances that are characteristic of cave and palaeokarst deposits make stratigraphic correlation extremely difficult and sometimes impossible, particularly if the critical boundary is not preserved or if it never existed.

Serious errors are common, even in the most diligently constructed cave and palaeokarst stratigraphies. Absolute and biostratigraphic methods may resolve these if the initial work is good. Advanced methods are unlikely to solve problems resulting from poor or uninformed stratigraphic work.

\section{The problem of recycling}

Recycling and reworking of both internal cave sediments and of surface derived materials is common in caves and karst systems generally. This can pose a major problem for litho and bio stratigraphers.

For example, cobbles and pebbles derived from the Lachlan Fold Belt are scattered over the landscape around the western margins of the Permo-Triassic Sydney Basin in eastern Australia. Some significant cavernous karsts e.g. Bungonia, Colong and Jenolan are developed in the Lachlan Fold Belt close to the margin of the Basin. Deposits of these cobbles and pebbles occur at a variety 
of levels in the landscape around the caves and are major components of the clastic sediments in the caves. It seems likely that these cobbles and pebbles were originally eroded and deposited by Permo-Carboniferous glaciation. Due to possibly many cycles of reworking, one cannot be certain which deposits are original, which are Mesozoic, which are Palaeogene and which were deposited quite recently.

\section{The lithification trap}

In non-karst geology, it is safe in most circumstances to assume that the degree of lithification is an indicator of age, i.e. unlithified or unconsolidated sediments are younger than consolidated, lithified ones. In the case of cave and palaeokarst deposits, this is a dangerous and misleading assumption.

Since almost all lithification in caves is due to cementation, not compaction, lithification is more related to permeability and depositional environment than to age. For example, sands are more likely to become cemented than muds, unless the muds were deposited in a carbonate-saturated environment. Recent work at Jenolan Caves (Osborne et al., in prep) has shown that the oldest relict sediments in the caves are plastic clays, not strongly-cemented sandstones.

As with not assuming superposition, it requires a degree of discipline to avoid the lithification trap.

\section{BIOSTRATIGRAPHIC}

One drawback with biostratigraphic approaches for ancient caves is the general lack of datable fossils in older cave sediments. While Pleistocene vertebrate fossils are abundant in cave deposits, older Cainozoic fossils are rare but not absent. Mesozoic vertebrate fossils (e.g. dinosaurs) however, have yet to be found in open cave deposits and have only been reported from a very small number of completely-filled palaeokarst caves. For example, an old and diverse vertebrate fauna has come from Early Triassic bone breccia in Czatkowice Quarry, near Krakow, Poland (Evans et al., 1998, Borsuk-Bialynicka et al., 1999).

Pollen and spores have been used to date some palaeokarst deposits back to the Devonian (Banks $\&$ Burns, 1962, see above) but the low survival rate of pollen in many cave situations has meant that pollen and spores have yet to be used to date old caves.

Fills produced by marine transgressions, such as caymanites should offer the best potential for biostratigraphic dating. The presence of marine fossils shows that these deposits are marine, but datable fossils must be recovered from the strata for them to be dated. While Lazlo Korpas (Korpas, 1998) has had success with dating Hungarian caymanites, my eastern Australian caymanites appear to contain only biostratigraphically useless crinoid ossicles.

Where datable fossils do occur, stratigraphic complexity and recycling are major problems. For example, the freshwater Tertiary Carl Creek Limestone at Riversleigh in northwest Queensland contains bones and bone fragments accumulated during its deposition. The limestone has later been invaded by a series of karst fissures. These are now filled and the fills also contain bones and bone fragments embedded in a carbonate-cemented matrix. The conventional approach of bulk solution of a sample will release a mixture of bones and fragments with three of four different ages. Without an understanding of the microstratigraphy of karst and collecting methods that take it into account, biostratigraphy will not succeed. 


\section{RELATIVE CLIMATIC METHODS}

There is a long history of making comparisons between cave morphology or sediments and climatic changes in the past. This has ranged from detailed correlation of sediments with established chronologies to vague alignment with past events, such as a "tropical past" in Europe and a wetter ("wetter times in the Miocene") or colder and wetter (Permian glacial) past in Australia.

A detailed correlation approach does not have much application to ancient caves at present, but could become useful as knowledge of ancient climates expands. Vague notions, however, can be both comforting and deceptive. When an inexplicable large cave passage, or a boulder conglomerate, is encountered, a wet tropical or wet glacial past can be an easy explanation. While I am too young to rely on "wetter times in the Miocene", I have fallen far too easily into attributing large cave passages and boulder conglomerates to Permian glacial runoff.

\section{RELATIVE ISOTOPIC METHODS}

Stable isotope ratios are commonly used to determine palaeoclimatic conditions. Stable isotopes can also be used for stratigraphic correlation between deposits and as the basis for dating by comparison with well-established palaeotemperature and palaeoisotope curves. They have the most potential for resolving the stratigraphy of sediments containing marine carbonates such as caymanites.

Both Stable O and Stable Sr determinations appear to have potential for isotopic correlation.

\section{CHEMICAL STRATIGRAPHY}

Archaeologists have used chemical stratigraphy based on trace elements and / or insoluble refractory elements. These may have potential for correlation between strata lacking any other means of correlation. In 1981, I attempted to use comparison of insoluble refractory compositions to solve some of the intractable stratigraphic problems in the complex sequence at the Wellington Caves Phosphate Mine, but with no real success.

This method probably does have potential, but it requires the application of significant funding and dedication of time.

\section{MORPHOSTRATIGRAPHIC}

Classical explanations for the origin of caves, e.g. Davis (1930) and Bretz (1942), were historical; they described the origin of caves as a sequence of events that could be read from the morphology of the resultant underground landforms. If history can be read from the morphology of caves, then caves must contain a stratigraphic sequence of morphological forms. Modern detailed studies of cave morphology and speleogens (e.g. Bella, 1998 \& Slabe, 1995) and an understanding of how caves evolve, can together form a basis for morphostratigraphy.

Using a combination of morphology and elevation Jeannin et al. (2000) were able to recognise eight successive phases of development in the Lake Thun Cave System in Switzerland and suggested that the oldest phases could possibly be Pliocene. While this is still young in the terms of this paper, it is an outstanding example of the application of morphostratigraphy to a meteoric cave.

The approach of Jeannin et al. is quite sophisticated. They recognised that aggradation, tectonism and glaciation may result in relative rises in the phreatic zone, while still retaining the overall assumption that the phreatic zone will, in general fall over time (i.e. that higher level caves will generally be older than lower level caves). 
The problem with this approach to morphostratigraphy when dealing with old caves is that as well as problems with aggradation, tectonism and glaciation, many have also undergone one or more period of non-meteoric, per ascensum speleogenesis. So rather than needing to be applied with caution, the assumption that higher-level cavities are older may need to be abandoned as a guiding principle.

The relationship between elevation and age is a powerful idea, not only in cave geomorphology, but also in the geomorphology of denudational landscapes on the surface. Just as the key idea of superposition needs to be abandoned with care and replaced with a reliance on crosscutting relationships in the stratigraphy of cave and palaeokarst sediments, the principle of increasing age with elevation needs to be abandoned with care and replaced with a reliance on crosscutting relationships between cavities and morphologies in the morphostratigraphy of ancient caves.

\section{REGIONAL GEOMORPHIC}

Dating cave systems by comparing them with the developmental histories of surface landforms has been attempted for many years. Cave levels are correlated with erosional or depositional events in the surrounding landscape whose age is considered to be established. One of the best examples of this approach, although not to caves thought to be ancient, is the work by Droppa $(1966,1972)$ refined by Bella \& Holubek (1996) on the caves of the Demanovska Valley, Slovakia. Droppa correlated "levels" in the caves with river terraces in the surrounding landscape. Bosak (2002) discussed how recent dating has challenged and modified this approach, leading to the conclusion that the caves are older than originally thought.

Comparison of cave features with regional geomorphic history works best if the caves are entirely of meteoric origin and if there has been a regular history of denudation. Problems arise where caves have become blocked with sediment, resulting in paragenesis, or where the geomorphic history involves both denudation and uplift.

Regional geomorphic comparisons may be more reliable in holokarsts than in impounded karsts, due to the greater supply of insoluble sediments in impounded karsts. This increases the potential for sequential cave and valley blockages followed by paragenesis and then exhumation (Osborne, 2000).

\section{What if the regional geomorphic interpretation changes?}

Regional geomorphic interpretations seem to be more susceptible to dramatic change than regional geological interpretations. This probably results from the greater degree of uncertainty involved in dating landforms compared with dating rocks. If the assumed age of a cave or palaeokarst is greatly dependent on a regional geomorphic interpretation, what happens if the geomorphic interpretation changes dramatically? This situation occurred in eastern Australia in the 1970s and there is much to learn from what happened.

The "traditional" idea was that the eastern Highlands of Australia had been uplifted by a regional epirogenic event, the Late Pliocene or Early Pleistocene "Kosciusko Uplift" (Browne, 1969). This uplift raised the "Miocene" plateau surfaces of the highlands and initiated their incision. Thus, valleys could be no older than about 2 million years and any caves developed in or near them had to be considerably younger.

By the 1970s the idea of young landscapes in the Eastern Highlands was being seriously chal- 
lenged. Dating of basalt flows by Wellman \& McDougall (1974) showed that basalts in the area were older than had been imagined. Basalt flows in the Endrick River, a valley incised into a sandstone plateau, were shown to be over 40 million years old. Young $(1977,1982)$ used this, and other evidence to suggest the landscapes in southeastern Australia originated before the Cainozoic. While the particulars of uplift remain a matter of debate, it is generally thought that the uplift of the Eastern Highlands is related to the opening of the Tasman Sea, during the Late Cretaceous. Thus, the likely date for the beginning of incision of valleys into the highlands plateaux surfaces increased during the 1970s by approximately 45 times (i.e. from about 2 million years to at least 90 million years ago).

The idea of the Kosciusko Uplift taking place two million years ago suited older karst geomorphologists such as J.N. Jennings who appeared to believe as a mater of faith that caves had to be young. Much research from the late 1960s through the 1970s focussed on Bungonia Caves in New South Wales. This is a plateau karst with some deep (by Australian standards) caves, incised by a $300 \mathrm{~m}$ deep limestone gorge. The caves do not reach to the bottom of the gorge, but rise in a perched spring $190 \mathrm{~m}$ above its floor. Jennings et al. (1972) linked the development of deep caves to the incision (rejuvenation) of the gorge which, following the Kosciusko Uplift idea, they assumed to be Plio-Pleistocene.

The work of Jennings et al. (1972) was revised by James et al. (1978), who were writing when the new ideas of landscape chronology were being promulgated. The new data disturbed them. It suggested that the earliest phase of speleogenesis could be Eocene (or older) and that the uplift causing the rejuvenation, so important to their ideas, was considerably older than Plio-Pleistocene. The response of James et al. was to reject the new data because: -

1. The idea of cave formation in the Early Tertiary offended prevailing notions of cave longevity.

2. The caves showed a "freshness of cave forms" inconsistent with great age.

3. The caves contained no demonstrably ancient fill.

So rather than changing the age of the caves when the regional landscape became 45 times older, James et al. argued that the caves were still young by disconnecting the $\mathrm{m}$ from the landscape: -

"Consequently, there need be no systematic relationship between the ... levels... in the cave and former erosion levels in Bungonia Gorge. ... most of the caves could be considerably younger than the rejuvenation, which formed the gorge. On an interpretation of this type it is no longer necessary to attribute the active levels of dynamic phreatic development in caves... to the early Tertiary" (James et al. 1978, p 61)

I later produced a revised chronology that accorded with the new regional geomorphic interpretation (Osborne, 1993a). I now believe that this chronology is probably also incorrect.

James et al. probably did not realise however that by disconnecting the cave levels from the incision of the gorge, they not only made it possible for the caves to be younger than the gorge, they also opened the possibility of the caves being older than the gorge. This situation may well apply to other complex cave systems whose evolution has traditionally been linked to terraces and valley incision.

We must carefully consider what to do if the regional geomorphic interpretation changes dramatically. Should the age of the karst features change with it, or should (or will) the old interpretation be supported, even if its basis is now unsound. 


\section{ABSOLUTE APPROACHES}

\section{ISOTOPIC METHODS}

Bosak (2002) provided an excellent summary these methods. While $\mathrm{Pb}-\mathrm{Pb}$ approaches are starting to make an impact of dating of palaeokarst calcites (Lundberg et al. 2001) there are few materials in ancient caves suitable for dating over the required time-scale. My recent experience has been with $\mathrm{K}$-Ar clay dating so I will use it as an example of the issues involved in dating old caves.

\section{K-Ar and Ar-Ar}

Potassium-Argon and argon-argon dating are excellent techniques for dating potassium-bearing minerals over a long time-scale. While usually thought of as being only applicable to igneous rocks, $\mathrm{K}-\mathrm{Ar}$ and Ar-Ar dating can now also be applied with confidence (and much more expense) to potassium-bearing clays such as illite.

Potassium-argon and Argon-Argon dating are now such a routine processes that problems with the dating are not very likely. Problems with the meaning of the date do remain however. When dating volcanic rocks the main problem is to decide with confidence if the item being dated is a flow, an intrusion, a mass of core stones or a detrital boulder that has entered the cave. This issue is discussed below.

With clay dating, the meaning is more difficult. Clays can be precipitated from solution, produced by alteration, produced by weathering or form during diagenesis. It is the relationship between the clay's origin, and how it came to be in the cave that is significant from a speleochronological point of view. Useful clays are those that have either been precipitated from solution or formed by alteration (for instance of a volcanic ash) in the cave. Their date should provide a minimum age for excavation of the cave.

\section{FISSION TRACK}

Fission track dating is an ideal method for dating zircons. It is an established method so, as with radiometric methods such as $\mathrm{K}-\mathrm{Ar}$ it is not the numbers that are open to question but what they mean. Zircons can be derived from tephra, metamorphics and from weathering of lavas. They are resistant the weathering and so can accumulate in residual sediments. Zircons are very good for dating volcanic events even if the source vent cannot be found, but in their usefulness in dating ancient cave deposits is problematic.

As materials coming from outside the cave, zircons should be able to set a maximum age for the deposit in which they occur, but as rare resistant grains, they might also be contaminants. This problem is discussed below.

\section{PALEOMAGNETISM}

Palaeomagnetism was, and perhaps still is, one of the great hopes of cave and palaeokarst stratigraphy. Unfortunately, it has not solved many of the problems and has some particular problems of its own. As Bosak (2002) rightly pointed out, complex conditions underground and breaks in deposition are major constraints on this method. If finding a long enough or complete enough section is a problem with relatively young caves and karsts, it is a nightmare in older systems where the record becomes even more fragmentary and the sample sections are shorter.

Palaeomagnetism is beginning to prove its worth in Neogene karst stratigraphy, but is yet to have 
much success with older material. In my experience, it is difficult to get palaeomagnetic specialists interested in complex karst problems, and so far, meaningful outcomes have yet to be forthcoming.

\section{COMBINED APPROACHES}

The history of complex old karsts is not likely to be resolved by any single approach, but by combining a whole range of approaches in a manner suitable to the particular study area. Just as complex caves and karsts have no single age, there is no single method for determining the ages of caves and palaeokarst.

Lithostratigraphy, morphostratigraphy and regional comparisons must form the foundation of combined approaches and come before attempts at biostratigraphy, absolute or other more complex methods. Combined approaches of necessity require a combination of skills and are well suited to teamwork. It is essential that the team leader is an experienced karst worker as many team members will be unfamiliar with caves and karst.

A good example of applying a combined approach to a "young" karst is the work of Adura et al. (2002) on hypogenic caves in Provence, France. Using cave morphology, speleothems, sediments and regional geomorphic history they constructed a history of karst development from the Middle Miocene to the present.

When applying a combined approach inside caves, a detailed study of cave morphology and geology can allow recognition and mapping of zones with specific geological and morphological characteristics (Figure 1). I call these speleomorphic units. Speleomorphic units are similar to soil-landscape units and terrain units in that they are characterised by the presence of a suite of features.

A speleomorphic unit is typically defined by an association of: -

I. cavity shape and size,

II. orientation and relationship to structure

III. presence or absence of particular speleogens

IV. wall texture, micromorphology, coatings etc

V. particular types of fillings such as sediments and speleothems

VI. relationships with palaeokarst

VII. relationships with other units.

A stratigraphy of speleomorphic units can be established by studying cross cutting relationships between them.

\section{BEARING THE BURDEN OF PROOF}

When a geologist finds the age of a rock using any standard method, there is a tendency to believe the result unless there are good reasons to doubt it. It is assumed, for instance that fossils in a rock were deposited with it, unless there is a particular reason to believe that they are inherited from some other source. Similarly, we do not often ask if the dated material was stored elsewhere before deposition in a sedimentary basin. In the case of ancient caves, my experience has been that these normal assumptions do not apply and that the burden is placed on me to demonstrate that the date is meaningful. 


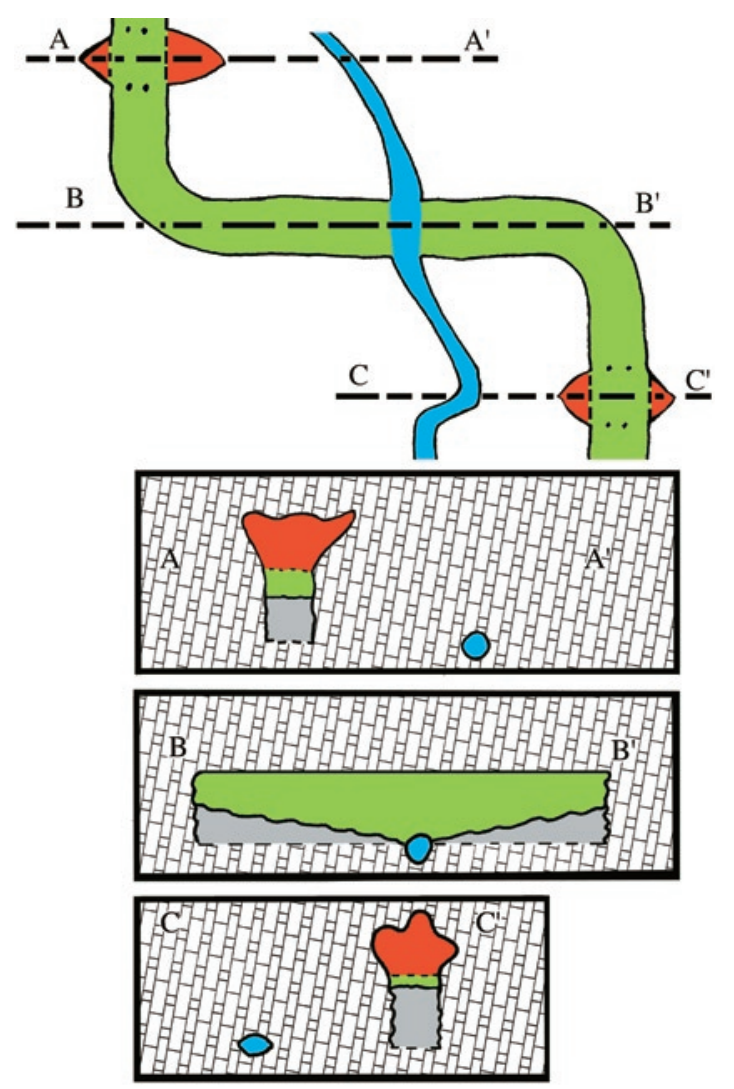

Figure 1: A sample speleomorphic map and sections, based on observations in part of Lannigans Cave, Colong Caves, New South Wales, Australia. The cave is developed in steeply westerly dipping limestone striking north-south with major vertical cross-joints striking east-west.

Three speleomorphic units are recognised here: -

Red: - $\quad$ Cupolas with an elliptical plan, guided by E-W jointing

Green: - Large paragenetic conduits, with smooth white-coated (? altered) limestone walls and flat ceilings. Solution notches are developed in the conduit walls. These contain relict deposits of cemented fluvial sediments (sands and gravels) shown as grey shading in sections.

Blue: - $\quad$ Small, semi-circular passages through which streams occasionally flow from south to north. Bedrock wall and ceiling is rough and jagged with sharp projections of less soluble material protruding from the limestone. The wall rock lacks any coating and has a grey colour.

Passage floors contain largely mobile sand and gravel deposits.

Note that the green unit intersects the red, and that where the blue unit intersects the green, there is no change in the walls of the green unit and that the relict sediments have been removed via the blue unit passages (section $B-B^{\prime}$ ).

This suggests that the red unit formed first, then the green unit, and that the blue unit developed after the relict sediments were deposited in the Green unit. 
Meeting this extra burden of proof can be quite onerous, as it requires investigating and rebutting a range of alternative explanations that may not have been thought of at first sight. This can make the process considerably more time consuming and expensive than would initially be expected.

\section{Is it a dyke, a flow or a mass of rolled core stones?}

Interpreting bodies of igneous rock exposed in caves can be quite difficult. It is also difficult sometimes to be certain in the field if a body of non-limestone rock is igneous or something else. Shale beds are frequently misidentified as dykes and vice versa and clastic dykes can easily be confused with weathered igneous ones.

As I have previously discussed (Osborne, 1986, 2000), it can be difficult to distinguish between, flows, dykes and sills that are exposed in caves (Figures 2, $3 \& 4$ ). If the igneous material is weathered the possibility for confusion increases, and it could be either a: -

i. spheroidally weathered dyke or sill,

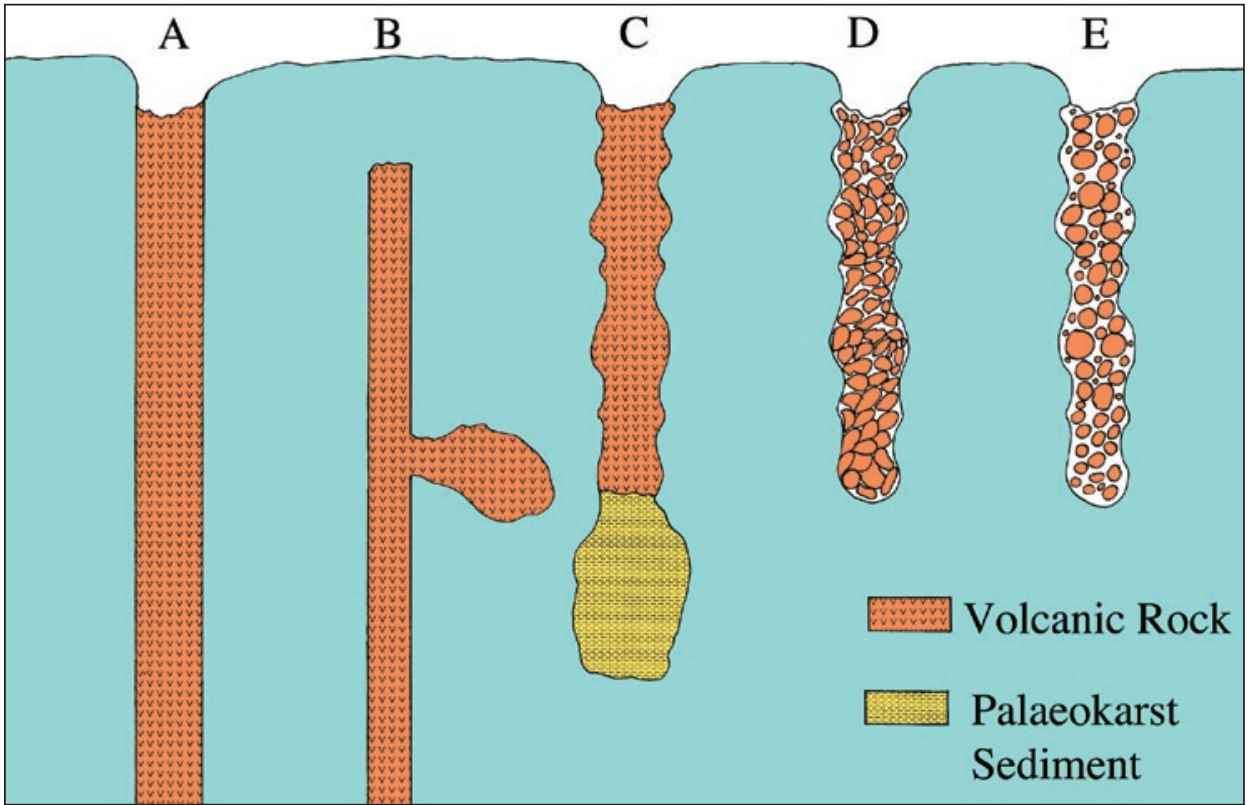

Figure 2: Planar volcanic features exposed in limestone caves:

A. Simple dyke, exposed on surface and in cave.

B. Blind dyke with no surface exposure. It has intersected and filled pre-existing cave.

C. Volcanic flow filling slot-shaped cave. Flow overlies older paleokarst deposit. (see Figure 3).

D. Slot filled with flow that reacted with water to form pillows. That pillows are shaped to fit against cave wall.

E. Slot filled with basalt core-stones, which have been transported into cave. Core stone are packed into cave, but are not shaped to fit against cave wall. Cave may be either older or younger than extrusion of basalt. 
ii. spheroidally weathered flow,

iii. flow that has interacted with water or wet sediment to form a pillow lava,

iv. collection of weathered core stones that have rolled into the cave from the surface.

Each has quite different implications for the age of the cave: -

i. a dyke or sill is older than the cave. Its age sets a maximum age for the cave, but its weathering age may date entry into the vadose zone.

ii. flows and pillow lavas are younger than the cave and set a minimum age for the cave iii. the core stones are probably older than the cave, but their age has no meaning as they

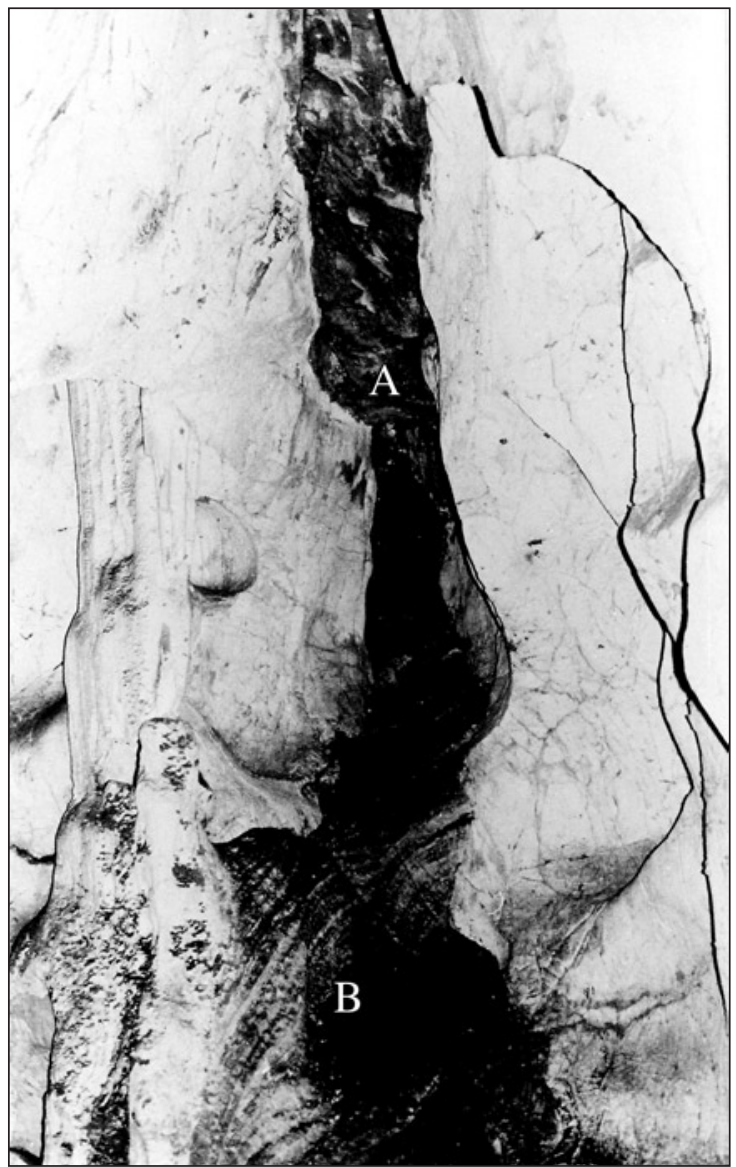

Figure 3: Is it a flow or a dyke?

Basalt ("A") above flowstone paleokarst deposit ("B"). Both are filling canyon-like passage that is exposed in the wall of more recent phreatic cave. Main Cave, Timor Caves, New South Wales, Australia, interpreted by Osborne (1986) as a flow filling a narrow passage with wall notches and stratigraphically overlying the flowstone. 
entered the cave after being eroded from weathered rock on the surface.

While unweathered flows and dykes can often be distinguished by the shape of their contact with the limestone, distinguishing between spheroidally weathered dykes, weathered pillow lava flows and partly-cemented masses of fallen core stones in caves is not only difficult to do, but more importantly is difficult to achieve to the satisfaction of sceptics.

\section{Did it just lie around on the surface (for millions of years) and enter the cave recently?}

The easiest refutation for an unexpectedly old date for a cave deposit is to contend that the sediment was originally deposited somewhere in the catchment of the cave and was then transported and re-deposited into the cave at a much later date. Thus the age of the deposit tells us little about the age of the cave, rather it dates the initial deposition outside the cave.

Countering this objection is very time-consuming. Firstly, all possible sources of the dated material in the catchment area need to be identified. With my clay dating work, this has meant testing all possible illite-bearing materials; rocks, weathered rocks and soils in the catchment, and identifying any with a significant illite content. The illite from these potential sources then had to be dated and its form and crystallinity compared with that of the dated illite in the cave samples.

The ideal outcome from such a process is to find that the dated material from the catchment is younger or has a substantially different age from that in the cave deposit and/or shows significant

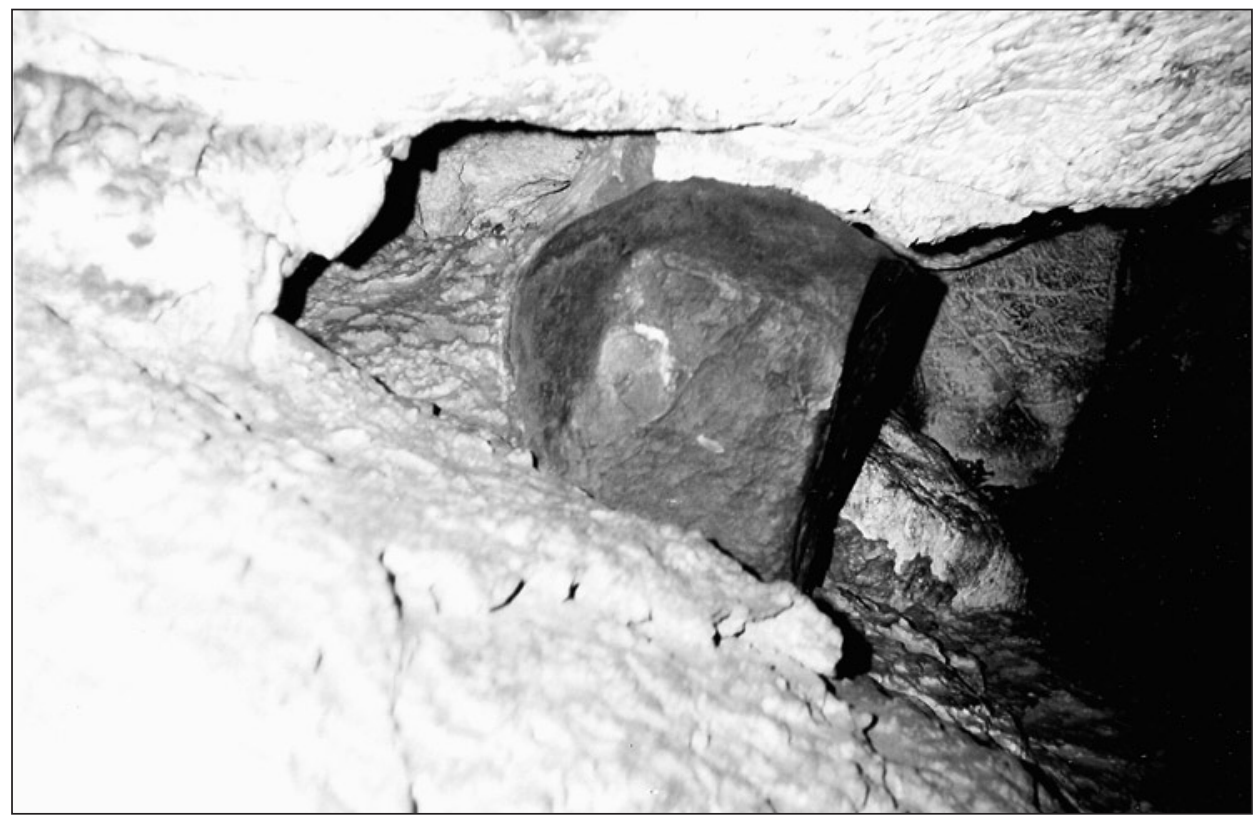

Figure 4: Is it an in-situ weathering remnant of a flow or a core stone that has just rolled in? Basalt boulder (dark, rounded in centre field) jammed in gently sloping cavity. Arch Cave, Borenore Caves New South Wales, Australia. The limestone adjacent to the cave is partly covered by a Miocene basalt flow. However, the age of the cave remains unclear. 
signs of transport (i.e. is clearly detrital) compared with the dated material from the cave. Unfortunately in the real world, the outcome is likely to be much less clear-cut.

\section{Was it really precipitated in the cave?}

In-situ flowstone, pool crystals and crystal linings have the great advantage that there is no doubt that they were deposited in the cave at their present location, whatever their age may be. If nothing else, their deposition date gives a minimum age for the excavation of the cave.

The relationship between other precipitated (or thought to be precipitated) minerals and the age of the cave is far less certain. Just how well crystallised and unabraded do clay, alunite, quartz, jarosite or other precipitated crystals need to be before they are accepted as autochthonous?

This is not a rhetorical question because surface-derived clastic cave sediments in impounded karsts are often quite immature. For example, feldspar, lithic and reasonably large mica grains are common in sands deposited in caves surrounded by granitic and felsic volcaniclastic terrains.

Another important issue is whether it is possible to distinguish between the abrasional effects of short distance transport within a cave and the relatively short surface transport into the cave from a surface store. This issue will need resolution if dating of precipitated material other than flowstone, pool crystals and crystal linings is to become a regular practice.

\section{Was it lowered?}

Some of the most difficult to refute objections to the simple interpretation of well-dated material in karsts came from "old school" karstologists. These objections invoke karst processes to cast doubt on what in normal circumstances would be an acceptable interpretation.

The position of basalt flows in the landscape has been one of the most powerful keys to understanding the geomorphic history of eastern Australia. As mentioned above, potassium-argon dating of flows in valleys in the 1970s dramatically expanded the time scale of eastern Australian landscape development.

A mass of basalt sitting on a terrace $80 \mathrm{~m}$ below the plateau surface in the main stream valley of a major cavernous karst would seem to have great potential for dating not only incision of the valley, but also cave development. Jennings (1982) undermined the significance of this basalt as follows: -

"Tertiary basalts of 22 my age flowed over the old Yarrangobilly River valley floor into which the incision of a gorge vitalised underground drainage and led to the formation of many caves. However little of the basalt seems still to be at the level where it solidified. Most remnants are shattered masses lowered varying amounts by solution subsidence. This process affects very much estimates of the ages of the caves that may be made."(Jennings, 1982, p45)

While proving solution lowering is difficult, the more difficult burden of disproving it remains to be seriously taken up. 


\section{CONCLUSIONS}

There are probably many ancient caves, palaeokarsts and ancient sections of complex caves waiting to be identified. It is likely that more detailed studies of caves and advances in dating methods will result in more cave deposits yielding dates older than $65 \mathrm{Ma}$.

While finding something to date and having it reliably dated may become simpler, establishing the meaning of a date or series of dates is likely to remain problematic. Despite all of the difficulties outlined in this paper, the main requirements for meeting the challenges of dating ancient caves and palaeokarsts are not beyond reach. These include: -

- Detailed and scrupulous fieldwork

- Use of speleomorphic mapping

- Recognition of stratigraphic issues: -

- $\quad$ lateral facies change

- $\quad$ abandoning superposition with care

- $\quad$ awareness of the lithification trap

- Abandoning with care reliance on age/elevation relationships

- Making a reasoned response to changes in geological or geomorphological interpretation

- Clear geological and geomorphological reasoning

\section{ACKNOWLEDGEMENTS}

This paper was presented at the 12th International Karstological School held at the Karst Research Institute ZRC SAZU, Postojna in June 2004. The author would like to thank the Director of the Institute, Dr Tadej Slabe and staff, particularly Drs Nadja Zupan-Hajna and Andrej Mihevc, for their hospitality and assistance. My attendance at the School was supported by a University of Sydney, College of Humanities and Social Sciences, Conference Travel Grant. P.J. Osborne assisted by proof reading the typescript.

\section{REFERENCES}

Adura, P., Bigot, J-Y. \& Mocochain, L., 2002. Hypogenic caves in Provence (France). Specific features and sediments. Acta carsologica. 31(3): 33-50.

Avais, J., 1972. Karst in France. In M. Herak \& V.T. Springfield Eds: Karst, Important Karst Regions of the Northern Hemisphere. Amsterdam, Elsevier: 129-118.

Banks, M.R. \& Burns, K.L., 1962. Eugenana Beds. Journal of the Geological Society of Australia. 9(2): 185-186.

Bella, P., 1998. Morfologike a geneticke znaky Ochtinskej Aragonitovej Jaskyne. Aragonit. 3: 3-7.

Bella, P \& Holubek, P., 1996. Jaskyna Stefanova C. 1 v Demänovskej Doline. Slovensky kras 34: 91-99.

Belloni, S., Martinis, B. \& Orombelli, G., 1972. Karst of Italy. In M. Herak \& V.T. Springfield Eds: Karst, Important Karst Regions of the Northern Hemisphere. Amsterdam, Elsevier: $85-128$.

Borsuk-Bialynicka, M., Cook, E., Evans, S.E. \& Maryanska, T., 1999. A microvertebrate assemblage from the Early Triassic of Poland. Acta Palaeontologia Polonica. 44(2): 176-188. 
Bosak, P., 1998. The evolution of karst and caves in the Koneprusy region (Bohemian Karst, Czech Republic), part II: hydrothermal paleokarst. Acta carsologica. 27(2): 41-61.

Bosak, P., 2002. Karst processes from the beginning to the end: How can they be dated. In F. Gabrovsek Ed: Evolution of karst: from prekarst to cessation. Ljubljana, Zalozba ZRC: 191-223.

Bretz, J.H., 1942. Vadose and phreatic features of limestone caverns. Journal of Geology. 50: $675-811$.

Browne, W.R., 1969. Geomorphology: General Notes. In G.H. Packham Ed: The Geology of New South Wales. Journal of the Geological Society of Australia. 16(1): 559-569.

Cas, R.A., Powell, C. McA., Fergusson, C.L., Jones, J.G., Roots, W.D. \& Fergusson, J., 1981. The Lower Devonian Kowmung Volcaniclastics: a deep-water succession of mass-flow origin, northeastern Lachlan Fold Belt, N.S.W. Journal of the geological Society of Australia. 28: 271-288.

Daranyi, F., 1972. Karst of Hungary. In M. Herak \& V.T. Springfield Eds: Karst, Important Karst Regions of the Northern Hemisphere. Amsterdam, Elsevier: 267-298.

Davis, W.M., 1930. The origin of limestone caves. Bulletin of the Geological Society of America. 41: 475-628.

Droppa, A., 1966. The correlation of some horizontal caves with river terraces. Studies in Speleology. 1: 186-192.

Droppa, A., 1972. Geomorphologicke pomery Demanovskev doliny. Slovensky kras. 10: 9-46.

Evans, S.E. \& Borsuk-Bialynicka, M., 1998. A stem-group frog from the Early Triassic of Poland. Acta Palaeontologia Polonica. 43 (4): 573-580.

Fergusson, J., 1980. Yerranderie crater. A Devonian silicic eruptive centre within the Bindook Complex, New South Wales. Journal of the geological Society of Australia. 27: 75-82.

Frank, R.M., 1973. Sedimentary and morphological development of the Borenore Caves, New South Wales (Part II). Helictite 11(2): 27-44.

Gale, S.J., 1992. Long-term landscape evolution in Australia. Earth Surface Processes and Landforms. 17: 323-343.

Herak, M., 1972. Karst of Yugoslavia. In M. Herak \& V.T. Springfield Eds: Karst, Important Karst Regions of the Northern Hemisphere. Amsterdam, Elsevier: 25-84

James, J.M., Francis, G. \& Jennings, J.N., 1978. Bungonia Caves and Gorge; a new view of their geology and geomorphology. Helictite. 16 (2): 53-63.

Jeannin, P-Y., Bitterli, P. \& Hauselmann, P., 2000. Genesis of a large cave system: case study of the North of Lake Thun System (Canton Bern, Switzerland). In A.B Klimchouk, D.C., Ford, A.N. Palmer \& W. Dreybrodt. Eds: Speleogenesis, Evolution of Karst Aquifers: Huntsville, National Speleological Society: 338-347.

Jennings, J.N., 1982. Principles and problems in reconstructing karst history. Helictite. 20(2): 37 52.

Jennings, J.N., James, J.M., Counsell, W.J. \& Whaite, T.M., 1972. Geomorphology of Bungonia Caves and Gorge. Sydney Speleological Society Occasional Paper. 4: 113-143.

Jennings, J.N., James, J.M, \& Montgomery, N.R., 1982. The development of the landscape. Sydney Speleological Society Occasional Paper. 8: 45-64.

Kahle, C.F., 1988. Surface and subsurface paleokarst, Silurian Lockport, and Peebles Dolomites, 
Western Ohio. In: N.P. James, N.P. \& Choquette, P.W., Eds: Paleokarst, New York, SpringerVerlag: 229-255.

Komatina, M., 1975. Development conditions and regionalization of karst. International Union of Geological Science Series B. Hydrology of karstic terrains. 3: 21-29.

Korpas, L., 1998. Palaeokarst Studies in Hungary, Budapest, Geological Institute of Hungary.

Lundberg, J., Ford, D.C. \& Hill, C.A., 2001. A preliminary U-Pb date on cave spar, Big A Canyon, Guadalupe Mountains, New Mexico, U.S.A. Journal of Cave and Karst Studies. 62(2): 144-148.

Martini, E. J., 1981. Early Proterozoic paleokarst of the Transvaal, South Africa. Proceedings of the 8th International Congress of Speleology, Huntsville, Alabama.1: 4-5.

Osborne, R.A.L., 1984a. Multiple karstification in the Lachlan Fold Belt in New South Wales: Reconnaissance Evidence. Journal and Proceedings of the Royal Society of New South Wales. 107: 15-34.

Osborne, R.A.L., 1984b. Lateral facies changes, unconformities, and stratigraphic reversals: Their significance for cave sediment stratigraphy. Cave Science: Transactions of the British Cave Research Association. 11(3): 175-184.

Osborne, R.A.L., 1986. Cave and landscape chronology at Timor Caves, New South Wales. Journal and Proceedings of the Royal Society of New South Wales. 119 (1/2): 55-76.

Osborne, R.A.L., 1993a. A new history of cave development at Bungonia, N.S.W. Australian Geographer. 24(1): 62-74.

Osborne, R.A.L., 1993b. The history of karstification at Wombeyan Caves, New South Wales, Australia, as revealed by palaeokarst deposits. Cave Science. 20 (1): 1-8.

Osborne, R.A.L, 2000. Paleokarst and its Significance for Speleogenesis. In A.B. Klimchouk, D.C. Ford, A.N. Palmer \& W. Dreybrodt. Eds: Speleogenesis, Evolution of Karst Aquifers: Huntsville, National Speleological Society: 113-123.

Osborne, R.A.L., 2002. Paleokarst: Cessation and Rebirth? In F. Gabrovsek Ed: Evolution of karst: from prekarst to cessation, Ljubljana, Založba ZRC: 97-114.

Osborne, R.A.L., Zwingmann, H., Pogson, R.E. \& Colchester, D.M., in prep. Carboniferous clay deposits from Jenolan Caves, New South Wales: implications for timing of speleogenesis and regional gelogy Submitted to Australian Journal of Earth Sciences

Palmer, A.N. \& Palmer, M.V., 2000. Speleogenesis of the Black Hills Maze Caves, South Dakota, U.S.A. In A.B. Klimchouk, D.C. Ford, A.N. Palmer \& W. Dreybrodt. Eds: Speleogenesis, Evolution of Karst Aquifers, Huntsville, National Speleological Society: 274-281.

Powell, C. McA \& Fergusson, C.A., 1979. Analysis of the angular discordance across the Lambian Unconformity in the Kowmung River-Murruin Creek area, eastern N.S.W. Journal and Proceedings of the Royal Society of New South Wales. 112: 37-42.

Slabe, T., 1995. Cave Rocky Relief and its Speleogenetical Significance. Ljubljana, Zbirka ZRC. Wellman, P. \& McDougall, I., 1974. Potassium-argon ages on the Cainozoic volcanic rocks of New South Wales. Journal of the Geological Society of Australia. 21: 247-272.

Young, R.W., 1977. Landscape development in the Shoalhaven River catchment of southeastern New South Wales. Z. Geomorph. N.F. 21(3): 262-283.

Young, R.W., 1982. The tempo of geomorphological change: evidence from southeastern Australia. Journal of Geology. 91: 211-230. 